\title{
Mucosal changes in gastric ulceration and their response to carbenoxolone sodium
}

\author{
H. W. STEER ${ }^{1}$ AND D. G. COLIN-JONES ${ }^{2}$ \\ From Southampton University Medical School
}

SUMMARY The epithelial differences between the normal stomach (six subjects) and 47 patients with gastric ulcers were compared. The concentrations of intraepithelial lymphocytes and polymorphonuclear leucocytes in lesser curve and prepyloric gastric ulcers were compared, and the effect of treatment with carbenoxolone sodium was studied. There is a statistically significant reduction in the total number of intraepithelial polymorphonuclear leucocytes before and after successful treatment with carbenoxolone sodium. There is also a statistically significant decrease in the quantity of intraepithelial lymphocytes in those patients with lesser curve gastric ulcers successfully treated with carbenoxolone sodium, whereas there is a significant increase in those patients with prepyloric gastric ulcers successfully treated and those patients in whom treatment failed. The value of counts of migrating white blood cells as a method of objectively assessing the effect of healing drugs upon the gastric mucosa is discussed.

Pseudomonas aeruginosa was found in many specimens obtained, and evidence is presented that this was not a contaminant. Carbenoxolone appeared to increase the amount of mucus but had little effect upon the number of bacteria found. The possible contribution of Pseudomonas aeruginosa to gastric ulceration is discussed.

The gastric mucosal barrier may be damaged in many ways. Amongst the causes of damage to the mucosa are the regurgitation of duodenal contents, including biliary reflux (Capper, 1967; Rhodes, 1972), and the ingestion of aspirin (Rhodes, 1972). Bacterial contamination of the gastric aspirate has been reported by Giannella, Broitman, and Zamcheck (1972), particularly where there is hypochlorhydria. It has been shown that patients with gastric ulcers tend to have a lower gastric acid output than normal (Baron, 1963).

Doll, Hill, Hutton, and Underwood (1962) demonstrated the beneficial effect of carbenoxolone sodium upon the healing of gastric ulcers, and numerous attempts have been made to determine how this effect is mediated. There is said to be an increased quantity of gastric mucus in the gastric mucosa after treatment with carbenoxolone sodium (Goodier, Horwich, and Galloway, 1967). Associated with this increased mucus production, there is an alteration in the molecular constitution of the mucus (Gheorghiu, Frotz, and Klein, 1971). Carbenoxolone sodium also increases the life span 1Present address: Nuffield Department of Surgery, Radcliffe Infirmary, Oxford.

'Present address: Queen Alexandra Hospital, Portsmouth. Received for publication 5 June 1975. of epithelial cells of the gastric mucosa (Lipkin, 1970).

Gear, Truelove, and Whitehead (1971) failed to demonstrate any change in the gastritis present in the gastric biopsies from patients whose medical treatment included carbenoxolone sodium. Similarly, Thomas, Hall, and Hislop (1972) found that carbenoxolone sodium did not produce any change in either the cellular infiltration or the type of gastritis noted before its administration.

The first part of this investigation examines the relationship between the activity of the gastritis, bacteria and gastric ulceration. The second part evaluates the effect of carbenoxolone sodium upon the gastric mucosa in gastric ulceration.

\section{Patients and Methods}

Forty-seven patients with benign gastric ulceration and six normal patients are included in our study. The six controls were patients who had had a gastroscopy during the investigation of abdominal pain. In all cases the gastric appearances were normal and the final diagnosis in no way involved the stomach. Biopsies were obtained at gastroscopy from 26 patients with ulceration of the lesser 
curvature of the stomach and from 13 patients with prepyloric ulceration. Specimens were taken from five regions of the stomach-prepylorus, incisura angularis, high on the lesser curve, high on the greater curve, and at the edge of the gastric ulcer. In addition, material was obtained from eight patients with lesser curve gastric ulceration at the time of partial gastrectomy. This tissue was processed for light microscopic as well as electron microscopic studies.

Sixteen patients were studied before and after treatment with carbenoxolone sodium. These were 12 patients (eight lesser curve gastric ulcers and four prepyloric gastric ulcers) successfully treated with carbenoxolone sodium and four patients in whom the treatment failed. The biopsies were taken from the five regions of the stomach previously described and in five patients duplicate biopsies were taken so that one could be processed for electron microscopic study and the other for histological and histochemical examination.

The specimens used for the histological and histochemical examination were fixed in phosphatebuffered $10 \%$ neutral formalin at $4^{\circ} \mathrm{C}$ for 24 hours. The tissues were dehydrated in a graded series of ethyl alcohol solutions, cleared in benzene and embedded in paraffin wax. Sections $6 \mu \mathrm{m}$ thick were cut and stained with haematoxylin and eosin, by the periodic acid-Schiff reaction (McManus, 1948), or by the Gram stain. The sections were then examined with the light microscope.

The material used for both light and electron microscopic studies was immediately fixed in $5 \%$ cacodylate-buffered glutaraldehyde ( $\mathrm{pH} 7 \cdot 3$ ) for four to 24 hours at $4{ }^{\circ} \mathrm{C}$ and then rinsed in cacodylate-buffered $10 \%$ sucrose $(\mathrm{pH} 7 \cdot 3)$ for 24 hours at $4^{\circ} \mathrm{C}$. Postfixation was carried out in veronal acetatebuffered $1 \%$ osmium tetroxide $(\mathrm{pH} \mathrm{7.3)}$ for two hours at $4^{\circ} \mathrm{C}$ after which the specimens were rinsed in chilled tap water $\left(4^{\circ} \mathrm{C}\right)$, dehydrated in a graded series of ethyl alcohol solutions, cleared in propylene oxide, and embedded in Araldite. Following this initial embedding, the blocks were trimmed, orientated and re-embedded in previously prepared moulds so that sectioning was at right angles to the luminal surface of the biopsy.

Sections $1 \mu \mathrm{m}$ thick were cut with a glass knife on an ultramicrotome and stained by the method of Richardson, Jarett, and Finke (1960). These sections were examined with a light microscope and cell counts were made with the aid of a calibrated grid square so that the number of polymorphonuclear leucocytes and lymphocytes in $0.0001 \mathrm{~mm}^{2}$ of the gastric epithelium could be determined. All sections were coded so that the specimens were examined blind. In addition, the number of bacteria related to $0.625 \mathrm{~mm}^{2}$ of gastric epithelium was calculated. The mucus content was assessed qualitatively from sections stained with methylene blue. Certain limited areas were selected from which sections approximately $25 \mathrm{~nm}$ thick were cut, stained with $1 \%$ uranyl acetate and Reynold's lead citrate, and examined with a Philips 300 electron microscope. Statistical analyses, using Student's $t$ test for paired and unpaired samples, were done on these calculations.

\section{Results}

The histological appearances of the gastric mucosa in normal people and those with gastric ulceration differ. The differences associated with the gastric

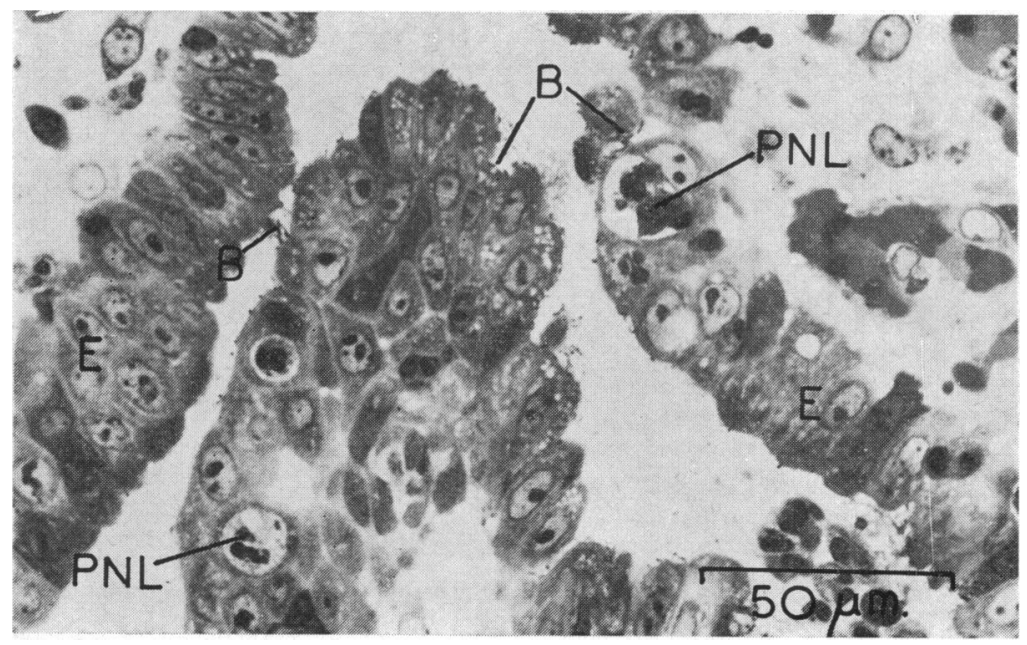

Fig 1 Mucosa from high on the lesser curve of a patient with a lesser curve gastric ulcer. Numerous bacteria (B) are related to the gastric epithelium (E). Polymorphonuclear leucocytes (PNL) are migrating through the gastric epithelium. Section stained with methylene blue Azur 11. 
epithelium include the occurrence of bacteria in those patients with gastric ulceration and the migration of cells through the gastric epithelium.

\section{BACTERIA}

Gram-negative bacteria (figs 1 and 2), up to about
$3 \mu \mathrm{m}$ long and about $0.5 \mu \mathrm{m}$ wide, are related to the gastric mucus-secreting cells in patients with gastric ulceration. The bacteria frequently occur in clusters and are found over extensive areas of the gastric mucosa but are not universally distributed over the surface of the stomach. These bacteria have not been

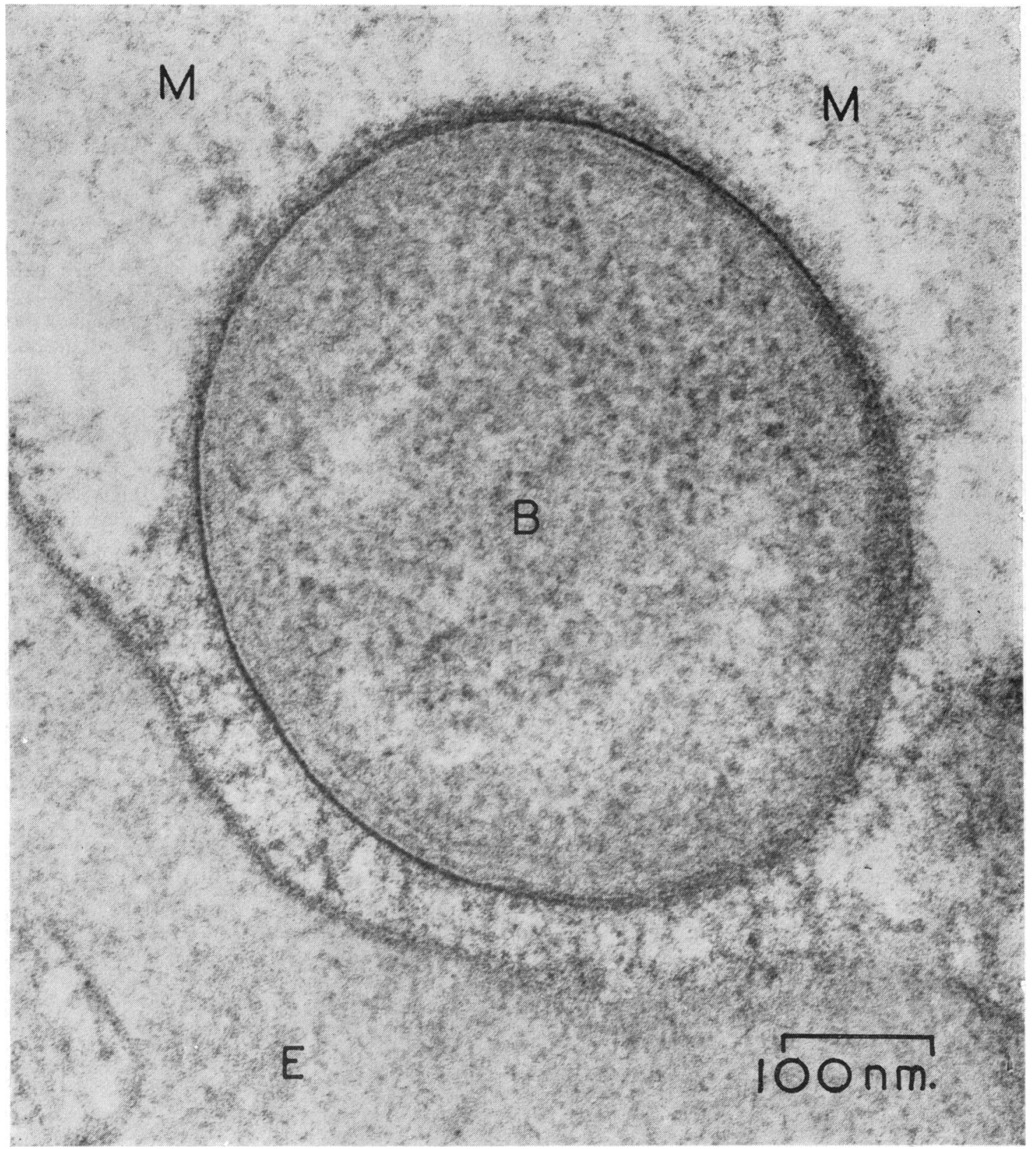

Fig 2 Bacterium (B) related to the surface of a gastric mucus-secreting cell (E). The bacterium has been sectioned transversely. Mucus (M) can be seen in the gastric lumen. 
seen in the biopsies from normal stomachs. In patients with gastric ulceration the bacteria are situated on the luminal surface of the epithelial cells and are normally related to the surface epithelium but are also seen in the necks of the gastric glands. They are found deep to the mucous layer covering the gastric mucosa. The gastric mucus-secreting cells related to these bacteria appeared to have a decreased mucus content compared with the gastric mucussecreting cells of the normal stomach. We have found that bacteria are not related to the goblet cells and are absent from areas of intestinal metaplasia.

Bacteria have been observed in specimens obtained at operation for gastric ulceration as well as in the biopsies obtained at gastroscopy. In addition, the phagocytosis of these bacteria by polymorphonuclear leucocytes has been seen occasionally (fig 3 ).

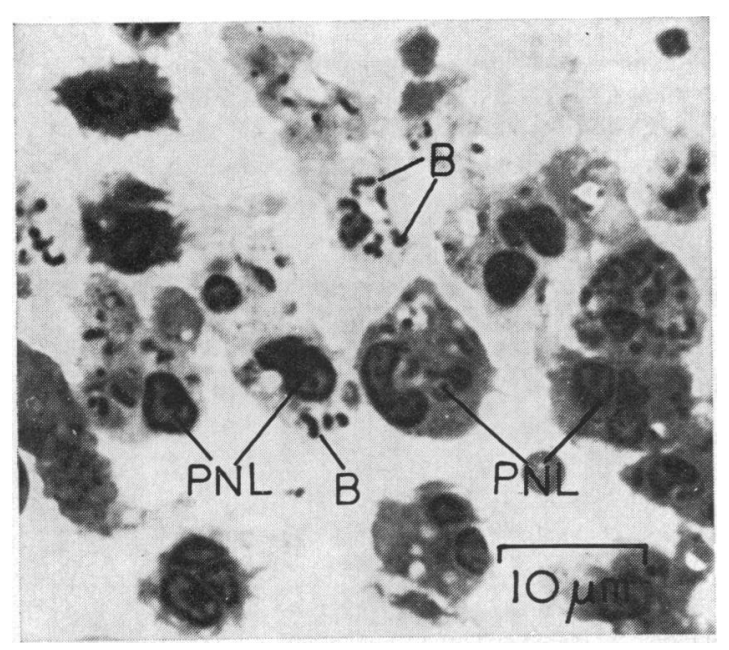

Fig 3 Polymorphonuclear leucocytes (PNL) in the gastric lumen. Numerous bacteria (B) have been phagocytosed by these cells. Section stained with methylene blue Azur 11.
Further identification of these bacteria was undertaken. The microorganisms were cultured on blood agar, McConkey's medium and cetrimide agar. The microorganisms are Gram-negative bacilli, motile, oxidase-positive, produce acid in glucose peptone water and produce ammonia from arginine. These results indicate that the bacterium is Pseudomonas aeruginosa. The presence of bacteria in relation to the gastric epithelium was confirmed when these specimens were examined with the electron microscope (fig 2).

The distribution of the bacteria in the stomach is variable and differs with the type of gastric ulceration. The relative distribution of the bacteria can be determined by counting the number of bacteria related to a given surface area of epithelium. Patients with lesser curve gastric ulcers can be divided into three categories (table I); those patients $(62 \%)$ with the maximum number of bacteria at the incisura angularis, those $(19 \%)$ with no specific site of maximum density, and those with no bacteria present in any of the biopsies $(19 \%)$. There is no statistically significant difference between the number of organisms found at comparable regions of the stomach in either of the first two categories.

Patients with prepyloric gastric ulceration have the maximum number of bacteria in those specimens from the region adjacent to the ulcer. There is no statistically significant difference between the number of bacteria found at comparable regions of the stomach when comparing prepyloric ulceration with either type of lesser curve gastric ulceration.

\section{POLYMORPHONUCLEAR LEUCOCYTES}

Cells migrate through the gastric epithelium. In the normal human stomach this is restricted to the occasional lymphocyte. In patients with gastric ulceration there is a considerable increase in the number of cells migrating through the gastric epithelium, the majority of them are polymorphonuclear

\begin{tabular}{|c|c|c|c|c|c|c|c|c|c|c|}
\hline \multirow[t]{2}{*}{ Type of Ulceration } & \multicolumn{5}{|l|}{ Bacteria } & \multicolumn{5}{|c|}{ Polymorphonuclear Leucocytes } \\
\hline & $\begin{array}{l}\text { Ulcer } \\
\text { Edge }\end{array}$ & Prepyloric & Incisura & $\begin{array}{l}\text { High } \\
\text { Lesser } \\
\text { Curve }\end{array}$ & $\begin{array}{l}\text { High } \\
\text { Greater } \\
\text { Curve }\end{array}$ & $\begin{array}{l}\text { Ulcer } \\
\text { Edge }\end{array}$ & Prepyloric & Incisura & $\begin{array}{l}\text { High } \\
\text { Lesser } \\
\text { Curve }\end{array}$ & $\begin{array}{l}\text { High } \\
\text { Greater } \\
\text { Curve }\end{array}$ \\
\hline $\begin{array}{l}\text { Lesser curve gastric ulcer } \\
\text { (type A) }\end{array}$ & $\begin{array}{r}360 \cdot 0 \\
\pm 142 \cdot 7\end{array}$ & $\begin{array}{r}261 \cdot 8 \\
\pm 115 \cdot 4\end{array}$ & $\begin{array}{r}603 \cdot 1 \\
\pm 165 \cdot 0\end{array}$ & $\begin{array}{r}251 \cdot 7 \\
\pm 111 \cdot 0\end{array}$ & $\begin{array}{r}290 \cdot 9 \\
\pm 149 \cdot 7\end{array}$ & $\begin{array}{r}26.6 \\
\pm 6.8\end{array}$ & $\begin{array}{r}4.4 \\
\pm 1.6\end{array}$ & $\begin{array}{r}18 \cdot 1 \\
\pm 5 \cdot 1\end{array}$ & $\begin{array}{r}14 \cdot 1 \\
\pm \quad 5 \cdot 3\end{array}$ & $\begin{array}{r}5 \cdot 2 \\
\pm 1 \cdot 8\end{array}$ \\
\hline $\begin{array}{l}\text { Lesser curve gastric ulcer } \\
\text { (type B) }\end{array}$ & $\begin{array}{r}185 \cdot 0 \\
\pm 139 \cdot 0\end{array}$ & $\begin{array}{r}144 \cdot 7 \\
\pm \quad 69 \cdot 0\end{array}$ & $\begin{array}{r}295 \cdot 5 \\
\pm 144 \cdot 6\end{array}$ & $\begin{array}{r}296 \cdot 7 \\
\pm 180 \cdot 0\end{array}$ & $\begin{array}{r}142 \cdot 7 \\
\pm 131 \cdot 0\end{array}$ & $\begin{array}{r}8 \cdot 5 \\
\pm 6 \cdot 3\end{array}$ & $\begin{array}{r}18 \cdot 3 \\
\pm 11 \cdot 3\end{array}$ & $\begin{array}{r}7 \cdot 2 \\
\pm 6 \cdot 3\end{array}$ & $\begin{array}{r}19 \cdot 3 \\
\pm 14 \cdot 3\end{array}$ & $\begin{array}{r}10.5 \\
\pm \quad 6.9\end{array}$ \\
\hline Prepyloric gastric ulcer & $\begin{array}{r}389 \cdot 7 \\
\pm 212 \cdot 7\end{array}$ & $\begin{array}{r}292 \cdot 3 \\
\pm 138 \cdot 0\end{array}$ & $\begin{array}{r}256 \cdot 8 \\
\pm 130.9\end{array}$ & $\begin{array}{r}144.9 \\
\pm \quad 93.0\end{array}$ & $\begin{array}{r}219 \cdot 2 \\
\pm \quad 72 \cdot 8\end{array}$ & $\begin{array}{r}4 \cdot 1 \\
\pm 1 \cdot 9\end{array}$ & $\begin{array}{r}2 \cdot 9 \\
\pm 1 \cdot 2\end{array}$ & $\begin{array}{r}1 \cdot 7 \\
\pm 0.9\end{array}$ & $\begin{array}{r}0.7 \\
\pm 0.5\end{array}$ & $\begin{array}{r}1.8 \\
\pm 0.9\end{array}$ \\
\hline
\end{tabular}

Table I The distribution of bacteria in patients with gastric ulceration with the corresponding distribution of polymorphonuclear leucocytes ${ }^{1}$

${ }^{1}$ Figures are the numbers of organisms $/ 0.625 \mathrm{~mm}^{2} \pm$ their standard error $( \pm \mathrm{SE})$ and the numbers of polymorphs/0.0001 mm² $( \pm \mathrm{SE})$ 
leucocytes and lymphocytes. The polymorphonuclear leucocytes migrate from local blood capillaries into the surrounding connective tissue. They subsequently pass into the overlying epithelium and are ultimately shed into the gastric lumen. No polymorphonuclear leucocytes were found migrating through the gastric epithelium in the normal stomachs we studied.

The number of polymorphonuclear leucocytes in the gastric epithelium varies with the type of gastric ulceration and with the area of the stomach which has been biopsied. The relative concentration of polymorphonuclear leucocytes in different specimens can be calculated by determining the number of these cells in a given area of gastric epithelium. The pattern of distribution of intraepithelial polymorphonuclear leucocytes in patients with lesser curve gastric ulcers can be divided into three main categories: those patients $(62 \%)$ with a maximum number of intraepithelial polymorphonuclear leucocytes adjacent to the ulcer (type A) (table I), those $(19 \%)$ with a minimum number of intraepithelial polymorphonuclear leucocytes adjacent to the ulcer (type B), and (19\%) with no migrating polymorphonuclear leucocytes in any of the biopsy specimens. There is no statistically significant difference between comparable areas in either type A or type B patients. However, when different areas are compared in patients with a type A lesser curve gastric ulcer it is found that there is a statistically significant difference between the ulcer edge and the prepylorus $(P<0.01)$, the ulcer edge and high on the greater curve $(\mathrm{P}<0.01)$, the prepylorus and the incisura angularis $(\mathrm{P}<0.02)$, as well as the incisura angularis and high on the greater curve $(P<0.05)$.

In those patients with prepyloric ulceration the pattern of distribution of the migrating polymorphonuclear leucocytes conforms to a single type: there is a maximum number of intraepithelial polymorphonuclear leucocytes adjacent to the prepyloric ulcer (table I). There are fewer migrating polymorphonuclear leucocytes than in patients having lesser curve gastric ulcers. When patients having the type A lesser curve gastric ulcer are compared with those having a prepyloric gastric ulcer there is a statistically significant difference between the biopsies from the ulcer edge $(\mathrm{P}<0.01)$, the biopsies from the incisura angularis $(P<0.01)$, and the biopsies from high on the lesser curve $(P<0.05)$.

\section{LYMPHOCYTES}

Lymphocytes migrate through the gastric epithelium. These lymphocytes are small lymphocytes and appear to originate from neighbouring lymphoid follicles in the gastric mucosa. The relative quantity of lymphocytes migrating through the gastric epithelium is determined by calculating the number of lymphocytes in a given area of gastric epithelium and comparing the results obtained from patients with the different types of gastric ulcers. Lymphocytes occur in small quantities in the gastric epithelium of the normal stomach but in gastric ulceration the number of intraepithelial lymphocytes is increased. There is no specific pattern in the distribution of intraepithelial lymphocytes in type A lesser curve gastric ulcers, in type B lesser curve gastric ulcers, and in patients with prepyloric gastric ulcers. There appear to be similar quantities in all regions and there is no statistically significant difference between the various kinds of gastric ulceration.

\section{EFFECT OF CARBENOXOLONE SODIUM}

In the 16 patients studied before and after treatment with carbenoxolone, there was an increase in the
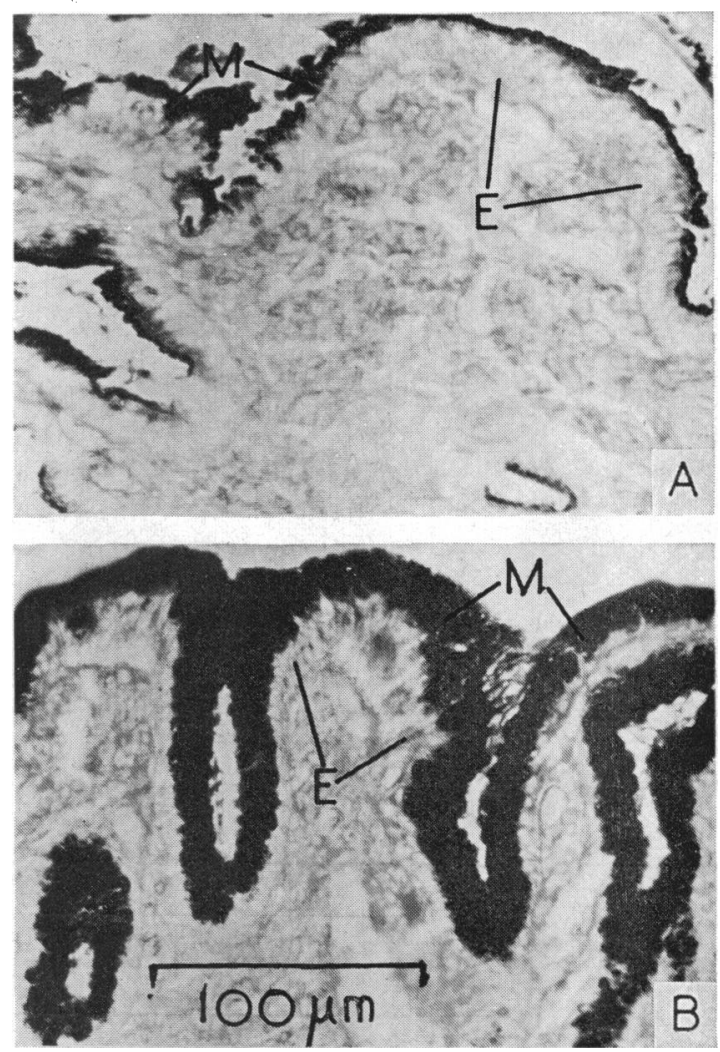

Fig 4 Mucosa from high on the greater curve of a patient with a lesser curve gastric ulcer. A is that specimen taken before treatment and $\mathrm{B}$ is the specimen obtained 10 weeks later after successful treatment with carbenoxolone sodium. The gastric mucus-secreting cells (E) have PAS-positive mucus (M) at their luminal surface. Section stained by the periodic acid-Schiff reaction. 
quantity of periodic acid-Schiff-positive material on the luminal surface of the gastric mucosa and also an increase in the amount of periodic acid-Schiffpositive material within the gastric mucus-secreting cells. Similar regions of the stomach in the same patient before and after treatment with carbenoxolone sodium are shown in figure 4. There was an increase in the thickness of the periodic acid-Schiffpositive material from about $5 \mu \mathrm{m}$ to about $15 \mu \mathrm{m}$. Before treatment with carbenoxolone sodium the gastric mucosa in the region of gastric ulcers tends to show the maximal epithelial derangement with considerable migration of intraepithelial cells. After treatment with carbenoxolone sodium, the surface epithelium attains a more ordered appearance and the number of migrating intraepithelial cells appears to decrease.

An attempt has been made to quantitate the changes induced by carbenoxolone sodium. The number of migrating intraepithelial cells of a specific type (polymorphonuclear leucocytes or lymphocytes) can be calculated for a given area of gastric epithelium and the quantity in an individual patient before and after treatment with carbenoxolone sodium compared. Thus, the increase or decrease in the number of cells caused by treatment in a particular region of the stomach is determined.

Successful treatment with carbenoxolone sodium decreased the number of intraepithelial polymorphonuclear leucocytes in those patients with lesser curve gastric ulcers (table II) and in the prepyloric ulcer patients. There is a statistically significant difference $(P<0.05)$ between the number of intraepithelial polymorphonuclear leucocytes before and after successful treatment with carbenoxolone sodium when the number migrating in all five specimens is analysed. There is also a decrease in those patients in whom the treatment with carbenoxolone sodium had failed. The relative quantity of this decrease in the number of migrating polymophonuclear leucocytes will depend upon the initial quantity of these cells migrating through the epithelium before treat- ment with carbenoxolone sodium. Thus, there is a smaller absolute decrease in those patients with prepyloric gastric ulcers.

The uniformity of response as depicted by the polymorphonuclear leucocytes is not apparent when considering intraepithelial lymphocytes. Successful treatment with carbenoxolone sodium in patients with lesser curve gastric ulcers produces a statistically significant decrease $(P<0.05)$ in the number of intraepithelial lymphocytes (table II), a decrease even more significant when the prepyloric biopsies are analysed $(\mathrm{P}<0.01)$. In patients with prepyloric gastric ulcers successfully treated with carbenoxolone sodium and in those patients in whom the treatment failed there is a statistically significant increase $(P<0.05)$ in the number of intraepithelial lymphocytes. Comparison of the intraepithelial lymphocyte response to carbenoxolone sodium in successfully treated gastric ulcers reveals a statistically significant difference between the lesser curve gastric ulcers and the prepyloric ulcers in the biopsies from the prepylorus $(P<0.001)$ and the incisura angularis $(\mathrm{p}<0.05)$. When comparing the patients with lesser curve gastric ulcers successfully treated with those patients whose ulcers failed to respond to carbenoxolone sodium, there is a statistically significant difference between the biopsies taken from the ulcer edge $(P<0.05)$, the prepylorus $(\mathrm{P}<0.01)$ and high on the lesser curve $(P<0.05)$. There is no statistically significant difference in the behaviour of the intraepithelial lymphocytes of patients with prepyloric ulcers successfully treated with carbenoxolone sodium: these two types behave in a similar manner when considering intraepithelial lymphocyte migration.

The bacteria observed in the stomachs of patients with gastric ulceration do not disappear upon successful treatment of the patient with carbenoxolone sodium. Generally, the number of bacteria tends to decrease but there is no statistically significant difference found.

\begin{tabular}{|c|c|c|c|c|c|c|c|c|c|c|}
\hline \multirow[t]{2}{*}{ Net Change } & \multicolumn{5}{|c|}{ Lymphocytes } & \multicolumn{5}{|c|}{ Polymorphonuclear Leucocytes } \\
\hline & $\begin{array}{l}\text { Ulcer } \\
\text { Edge }\end{array}$ & Prepyloric & Incisura & $\begin{array}{l}\text { High } \\
\text { Lesser } \\
\text { Curve }\end{array}$ & $\begin{array}{l}\text { High } \\
\text { Greater } \\
\text { Curve }\end{array}$ & $\begin{array}{l}\text { Ulcer } \\
\text { Edge }\end{array}$ & Prepyloric & Incisura & $\begin{array}{l}\text { High } \\
\text { Lesser } \\
\text { Curve }\end{array}$ & $\begin{array}{l}\text { High } \\
\text { Greater } \\
\text { Curve }\end{array}$ \\
\hline $\begin{array}{l}\text { Lesser curve gastric ulcer, } \\
\text { successful treatment }\end{array}$ & $\begin{array}{c}-5 \cdot 4 \\
( \pm 3 \cdot 4)\end{array}$ & $\begin{array}{l}-11 \cdot 1 \\
( \pm \quad 3 \cdot 0)\end{array}$ & $\begin{array}{l}-18.4 \\
( \pm 10.7)\end{array}$ & $\begin{array}{l}-15 \cdot 2 \\
( \pm \quad 8 \cdot 1)\end{array}$ & $\begin{array}{l}+2 \cdot 6 \\
( \pm 4 \cdot 8)\end{array}$ & $\begin{array}{c}-13 \cdot 7 \\
( \pm 9 \cdot 5)\end{array}$ & $\begin{array}{l}-10 \cdot 1 \\
( \pm 12 \cdot 4)\end{array}$ & $\begin{array}{l}-6 \cdot 6 \\
( \pm 8 \cdot 2)\end{array}$ & $\begin{array}{l}-24 \cdot 5 \\
( \pm 15 \cdot 8)\end{array}$ & $\begin{array}{l}-\cdot 5 \cdot 4 \\
( \pm \quad 2 \cdot 8)\end{array}$ \\
\hline $\begin{array}{l}\text { Prepyloric gastric ulcer, } \\
\text { successful treatment }\end{array}$ & & $\begin{array}{l}+18.0 \\
( \pm \quad 5.9)\end{array}$ & $\begin{array}{l}+36 \cdot 3 \\
( \pm 24 \cdot 5)\end{array}$ & $\begin{array}{l}+21 \cdot 8 \\
( \pm 19 \cdot 3)\end{array}$ & $\begin{array}{l}+19 \cdot 2 \\
( \pm 10 \cdot 4)\end{array}$ & & $\begin{array}{l}-14 \cdot 2 \\
( \pm 12 \cdot 2)\end{array}$ & $\begin{array}{l}-2 \cdot 0 \\
( \pm 2 \cdot 0)\end{array}$ & $\begin{array}{l}-1 \cdot 3 \\
( \pm 1 \cdot 3)\end{array}$ & $\begin{array}{l}0 \\
( \pm 0)\end{array}$ \\
\hline $\begin{array}{l}\text { Gastric ulceration, } \\
\text { failed treatment }\end{array}$ & $\begin{array}{l}+49 \cdot 6 \\
( \pm 34 \cdot 5)\end{array}$ & $\begin{array}{l}+23 \cdot 4 \\
( \pm 14 \cdot 6)\end{array}$ & $\begin{array}{l}-3 \cdot 4 \\
( \pm 3 \cdot 1)\end{array}$ & $\begin{array}{l}+46 \cdot 7 \\
( \pm 32 \cdot 4)\end{array}$ & $\begin{array}{l}+18 \cdot 9 \\
( \pm 26 \cdot 1)\end{array}$ & $\begin{array}{c}+9 \cdot 2 \\
( \pm 11 \cdot 0)\end{array}$ & $\begin{array}{l}-5 \cdot 2 \\
( \pm 4 \cdot 0)\end{array}$ & $\begin{array}{l}-13 \cdot 0 \\
( \pm 12 \cdot 9)\end{array}$ & $\begin{array}{l}-12 \cdot 5 \\
( \pm 12 \cdot 5)\end{array}$ & $\begin{array}{l}-2 \cdot 6 \\
( \pm 5 \cdot 5)\end{array}$ \\
\hline
\end{tabular}

Table II The effect of carbenoxolone upon the migration of lymphocytes and polymorphonuclear leucocytes through the gastric epithelium 1

${ }^{1}$ Figures are the numbers of cells/0-0001 $\mathrm{mm}^{2} \pm$ their standard error. 


\section{Discussion}

Bacteria have been observed in the biopsies from about $80 \%$ of patients suffering from gastric ulceration. The microorganism has been identified bacteriologically as Pseudomonas aeruginosa. The possibility that the bacteria are contaminants introduced at the time of biopsy is unlikely. They have been seen in specimens obtained at open operation (not involving the use of a gastroscope or gastroscopic biopsy forceps) as well as at gastroscopy. They are not found in all the gastroscopic specimens and are absent from human stomachs which are radiologically and gastroscopically normal. They have a peculiar localization, being limited to the mucosal surface of the specimens and occurring at this surface on the deep aspect of the covering mucus as well as in the gastric pits. They are not found on the superficial surface of the gastric mucus which is that surface coming into contact with the biopsy forceps and are absent from the surfaces of the biopsy which are not the luminal surface. The bacteria are not found related to areas of intestinal metaplasia. Some bacteria have been phagocytosed by polymorphonuclear leucocytes. It is difficult to explain these observations if the bacteria are contaminants because the biopsies are immediately placed in fixative. For these reasons the ability to culture Pseudomonas aeruginosa from gastroscopes (Axon, Phillips, Cotton, and Avery, 1974) cannot explain the present results.

A recent analysis of bacteria in gastric aspirates (Giannella et al, 1972) has revealed a significant increase in patients with hypochlorhydria when compared with normal patients. The inability of these authors to detect significant numbers of Pseudomonas aeruginosa could be related to the fact that they did not culture the gastric mucosa and, as already stated, the microorganisms are related to the deep aspect of the gastric mucus; they do not seem to thrive in the superficial aspect related to the gastric fluid. Associated with the findings of bacteria in the gastric aspirates of patients with hypochlorhydria, it has been shown that patients with gastric ulcers tend to have a lower gastric acid output than normal subjects (Baron, 1963). The regurgitation of duodenal contents into the stomach has recently been increasingly studied as an aetiological factor in gastric ulceration. Higher concentrations of bile salts have been found in the gastric aspirate of patients with gastric ulcers than in normal controls (Du Plessis, 1965; Capper, 1967; Rhodes, Barnardo, Phillips, Rovelstad, and Hofmann, 1969). Lysolecithin, a phospholipid which is produced when pancreatic juice and bile mix in the duodenum, has been found in significantly greater quantity in the gastric aspirate of patients with gastric ulcer than in normal controls (Johnson and McDermott, 1974).

Pseudomonas aeruginosa is a Gram-negative bacterium which grows successfully in culture media containing bile salts. Thus, the regurgitation of duodenal contents into the stomach would not inhibit the growth of this microorganism in the stomach. Pseudomonas aeruginosa has been found in those areas of the stomach which are subjected to biliary reflux. At these sites they are not exposed to the maximal effect of the gastric secretion. Another criterion for the growth of this microorganism in the stomach is the presence of mucus produced by the gastric mucus-secreting cells; they were not found in relation to the goblet cells of intestinal metaplasia. The greatest quantity occur either at the site of gastric ulceration, adjacent to the gastric ulcer, or between the pylorus and the gastric ulcer. Their preferential location deep to the gastric mucus protects them from the hostile environment of the gastric secretion, especially as biliary reflux is considered to be an intermittent variable phenomenon (Capper, 1967). The tendency to find the maximum concentration of bacteria nearer the pylorus in prepyloric ulceration compared with lesser curve ulceration is consistent with the greater degree of hypochlorhydria associated with lesser curve ulceration (Baron, 1963). Pseudomonas aeruginosa is known to attack several carbohydrates oxidatively (Wilson and Miles, 1964) but whether it attacks the carbohydrate moiety of gastric mucus has yet to be determined. The localization of the bacteria in the present study indicates its preference for gastric mucus. If the bacteria are mucolytic they would decrease any mucus barrier in the stomach and could contribute to the aetiology of gastric ulceration. If Pseudomonas aeruginosa does produce a significant reduction in the gastric mucosal barrier then the repeated consumption of contaminated foods and fluids, for example antacids (Robinson, 1971), could be prejudicial to the healing of the ulcer

The concentration of polymorphonuclear leucocytes in the gastric epithelium is a measure of the activity of the gastritis, which represents the insult to the gastric mucosa by the gastric contents at the moment of taking the gastric biopsy. It is not surprising that the concentration of these cells is maximal at, adjacent to, or near the site of gastric ulceration where the insult would be expected to be maximal.

The specific causes for the polymorphonuclear leucocyte migration has not been elucidated but a single aetiological factor is unlikely. Bacteria have been identified in association with gastric ulceration, and the phagocytosis of bacteria by poly- 
morphonuclear leucocytes has been observed but there is no absolute correlation between the density of microorganisms and the concentration of polymorphonuclear leucocytes on the gastric epithelium. Indeed, some biopsies show numerous polymorphonuclear leucocytes migrating through the gastric epithelium without any microorganism related to that gastric epithelium on our specimens.

Whether Pseudomonas aeruginosa produces a leucosidin capable of inducing polymorphonuclear leucocyte migration has yet to be demonstrated.

The quantity of gastric mucus is said to be increased by carbenoxolone sodium (Goodier et al, 1967). There is a considerable increase in the amount of stainable mucus not only on the surface of the gastric mucosa but also in the apices of the gastric mucus-secreting cells of our biopsies.

Carbenoxolone sodium causes a significant reduction in the total number of intraepithelial polymorphonuclear leucocytes in those patients successfully treated. There is a statistically significant decrease in the quantity of intraepithelial lymphocytes in those patients with lesser curve gastric ulcers successfully treated with carbenoxolone sodium whereas there is a statistically significant increase in those patients with prepyloric gastric ulcers successfully treated and in those patients in whom treatment failed. We had hoped that the migration of cells would prove a useful tool for objectively assessing the effect of healing drugs and as an indicator of those patients who would respond to treatment, but the wide range in numbers of migrating cells yields uncertain results in the individual case. The present results indicating that carbenoxolone sodium does have a beneficial effect on the gastric mucosa are contrary to the observations of Thomas et al (1972) but these investigators did not carry out any quantitative analysis on intraepithelial cell migration.

Carbenoxolone sodium does not significantly alter the number of bacteria found in the stomach. However, such an observation is still consistent with the possibility that Pseudomonas aeruginosa is an aetiological factor in gastric ulceration. Carbenoxolone sodium is said to increase the amount of gastric mucus so that the gastric mucosal barrier is in- creased, but the increase is not associated with an increased number of bacteria. It is possible that persistence of these mucolytic bacteria contributes to the high incidence of recurrent ulceration.

We gratefully acknowledge the encouragement and facilities afforded to us by Professor D. Bulmer and the skilled technical assistance of $\mathrm{Mr} \mathrm{B}$. Backhouse and Mr D. Morrison. Dr A. R. MacKenzie kindly assisted with the bacterial identification.

\section{References}

Axon, A. T. R., Phillips, I., Cotton, P. B., and Avery, S. A. (1974). Disinfection of gastrointestinal fibre endoscopes. Lancet, 1 , 656-658.

Baron, J. H. (1963). An assessment of the augmented histamine test. in the diagnosis of peptic ulcer. Gut, 4, 243-253.

Capper, W. M. (1967). Factors in the pathogenesis of gastric ulcer. Ann. roy. Coll. Surg., 40, 21-35.

Doll, R., Hill, I. D., Hutton, C., and Underwood, D. J. II (1962). Clinical trial of a triterpenoid liquorice compound in gastric and duodenal ulcer. Lancet, 2, 793-796.

Du Plessis, D. J. (1965). Pathogenesis of gastric ulceration. Lancet, 1, 974-978.

Gear, M. W. L., Truelove, S. C., and Whitehead, R. (1971). Gastric ulcer and gastritis. Gut, 12, 639-645.

Gheorghiu, T., Frotz, H., and Klein, J. (1971). Experimentelle und klinische Untersuchungen zum Mechanismus der Carbenosolon -Wirkung. I: Einfluss von Carbenoxolon auf die MagenshaftMucus-Sekretion der ،Ratte. Verh. Dtsch. ges. inn. Med., 77, 511-515.

Giannella, R. A., Broitman, S. A., and Zamcheck, N. (1972). Gastric acid barrier to ingested microorganisms in man: studies in vivo and in vitro. Gut, 13, 251-256.

Goodier, T. E. W., Horwich, L., and Galloway, R. W. (1967). Morphological observations on gastric ulcers treated with carbenoxolone sodium. Gut, 8, 544-547.

Johnson, A. G., and McDermott, S. J. (1974). Lysolecithin: a factor in the pathogenesis of gastric ulceration. Gut, 15, 710-713.

Lipkin, M. (1970). Carbenoxolone sodium and the rate of extrusion of gastric epithelial cells. In Carbenoxolone Sodium, edited by J. H. Baron and F. M. Sullivan, pp. 11-17. Butterworths, London.

McManus, J. F. A. (1948). Histological and histochemical uses of periodic acid. Stain Technol., 23, 99-108.

Rhodes, J. (1972). Etiology of gastric ulcer. Gastroenterology, 63, 171-182.

Rhodes, J., Barnardo, D. E., Phillips, S. F., Rovelstad, R. A., and Hofmann, A. F!'(1969). Increased reflux of bile into the stomach in patients with gastric ulcer. Gastroenterology, 57, 241-252.

Richardson, K. C., Jarett, L., and Finke, E. H. (1960). Embedding in epoxy resins for ultrathin sectioning in electron microscopy. Stain Technol., 35, 313-323.

Robinson, E. P. (1971). Pseudomonas aeruginosa contamination of liquid antacids: a study. J. Pharm. Sci., 60, 604-605.

Thomas, E., Hall, P., and Hislop, I. G. (1972). Observations on the histology of the gastric mucosa in chronic gastric ulcer. Amer. J. dig. Dis., 17, 683-688.

Wilson, G. S., and Miles, A. A. Eds. (1964). In Topley and Wilson's Principles of Bacteriology and Immunity, 5th ed. Arnold London. 